\title{
HEPATOPROTECTIVE POTENTIAL OF Physalis peruviana L. FRUIT EXTRACTS ON LEAD ACETATE INTOXICATED RATS
}

\author{
Revathi C, Vadivelu J* \\ Department of Biochemistry, Sri Akilandeswari Women's College, Wandiwash, Tamil Nadu, India - 604408
}

Received - April 25, 2021; Revision - June 05, 2021; Accepted - June 17, 2021

Available Online - June 25, 2021

DOI: http://dx.doi.org/10.18006/2021.9(3).353.361

\section{KEYWORDS \\ Physalis peruviana \\ Fruit}

Hepatoprotective

Albino rat

\begin{abstract}
Physalis peruviana has been widely used as a medicinal herb for treating various diseases since ancient times. This study aimed to examine the hepatoprotective potential of the ethanolic extract of $P$. peruviana fruit (EPPF) against lead acetate (LA) intoxicated male albino rats. The experimental rats were divided into ten groups of 4 animals. Animal of Group I served as normal, Group II animals were administered orally $15 \mathrm{mg} / \mathrm{Kg}$ body weight of LA, Group III to V animals received EPPF $150 \mathrm{mg} / \mathrm{kg}$, $300 \mathrm{mg} / \mathrm{kg}$ and $600 \mathrm{mg} / \mathrm{kg}$ respectively, Group VI animals received standard silymarin $50 \mathrm{mg} / \mathrm{kg}$, and Group VII to X were treated with LA $(15 \mathrm{mg} / \mathrm{kg})$ with EPPF $150,300,600$ and std $50 \mathrm{mg} / \mathrm{kg}$, orally for 32 days respectively. The degree of protection was measured by estimating hematological parameters such as $\mathrm{Hb}, \mathrm{RBC}, \mathrm{WBC}, \mathrm{PCV}$, platelets, MCV, MCHC, and ESR and biochemical parameters such as urea, creatinine, Cholesterol, HDL, LDL, VLDL, bilirubin, SGOT, SGBT, ALP, GGT, protein, albumin and globulin. Lead acetate induced alterations of hematological and biochemical parameters were observed in group II animals and these levels brought back to normal in the animals treated with EPPF at the concentrations of 150,300 and $600 \mathrm{mg} / \mathrm{kg}$ which was significantly similar to silymarin treated animals. The data of the results obtained depicted that the fruit extract of P. peruviana was found to have promising protective efficacy against lead acetate induced liver toxicity.
\end{abstract}

* Corresponding author

E-mail: vadivelu2015@gmail.com

Peer review under responsibility of Journal of Experimental Biology and Agricultural Sciences.

Production and Hosting by Horizon Publisher India [HPI] (http://www.horizonpublisherindia.in/).

All rights reserved.
All the articles published by Journal of Experimental Biology and Agricultural Sciences are licensed under a Creative Commons Attribution-NonCommercial 4.0 International License Based on a work at www.jebas.org.

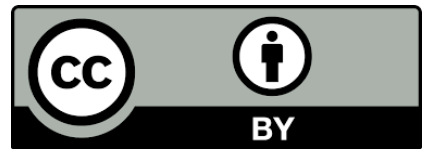




\section{Introduction}

Lead is a well-known heavy metal known as an environmental pollutant and has harmful effects on human health (Gagan et al., 2012). It is transferred via the food chain to human and animals (Azman et al., 2015); and its toxicity depends on its chemical nature administrated to the animal, the route of administration, and the frequency and duration administered to animals (Chaurasia et al., 2016; Kumaresan et al., 2016). Further, lead provokes excess production of reactive oxygen species (ROS) and consequently improves lipid peroxidation, reduces the saturated fatty acids, and increases the unsaturated fatty acid contents of membranes. Moreover, it has been shown to elicit ROS production in a range of cells leads to oxidative stress (Gautam \& Flora, 2010; Sharma et al., 2011; El-Neweshy \& El-Sayed, 2011; Mobarak \& Sharaf, 2011). The liver is an essential organ that can eliminate toxic substances and defend the other organs that exposure to various toxin sources. About $33 \%$ of the lead is accumulated in liver tissue after absorption and causes changes in its regular metabolic activities due to its toxicity and modification in histological structures (Vineeth Daniel et al., 2019).

Epidemiological data specify that fruit and vegetable consumption caused a reduction in morbidity and mortality from several dangerous diseases and this is due to their high content in polyphenols, vitamins, minerals, and other bioactive molecules (Wang et al., 2014; Hu et al., 2014). Reports on the rising role and values of medicinal plant products in the maintenance and optimization of health have led to research on the efficacy of these medicinal plants/nutrient products' effects on the amelioration of the metal-induced toxicity (Nwokocha et al., 2012).

Physalis peruviana (Family: Solanaceae) is an herbaceous, semishrub plant, annual in the temperate zones and perennial in the tropics and sub-tropics. It was first reported in the Andean region, mostly Colombia, Peru, Ecuador, and presently cultivated in several regions throughout the world (Osorio-Guarin et al., 2016; Park et al., 2016; Adebayo et al., 2019). P. peruviana is widely used in folk medicine for treating diseases such as malaria, asthma, hepatitis, dermatitis, cancer, diuretic, rheumatism, antispasmodic, diuretic, antiseptic, sedative, analgesic, cataract-cleaning, antidiabetic, and anti-parasitic properties (Kasali et al., 2013; Cakir et al., 2014; Joshi \& Joshi, 2015; Lashin \& Elhaw, 2016; Eken et al., 2016; Higaki et al., 2016; Chang et al., 2016). Various therapeutic applications have been attributed to the cape gooseberry, including anti-asthmatic, antiseptic, strengthener of the optic nerve, remedy for throat infections, anti-ulcer potential, antiparasitic, antiamoebic, as well as albumin from kidneys, controlling cholesterol level (Arun \& Asha, 2007; Hassanien, 2011). The study aimed to evaluate the ability of the ethanol extract of $P$. peruviana fruit to reduce the hepatotoxic effects of lead acetate in male rats by estimating levels of important hematological parameters, liver enzymes, total serum protein, and bilirubin.

\section{Materials and Methods}

The fruits of $P$. peruviana were collected from 2-3 months old healthy plants growing at the Medicinal plant Garden, Sri Akilandeswari Women's College, Wandiwash, Tamil Nadu, India. The plant was taxonomically identified and confirmed by the authorities of Dr. P. Jayaraman, Director, Plant anatomy research center, Chennai, Tamil Nadu, India. The fruits were subjected to shade drying for 10-15 days and it was powdered mechanically and stored in an air-tight container. About $40 \mathrm{gm}$ of fruit powder was extracted with $200 \mathrm{ml}$ of ethanol; this extraction was carried out by hot percolation method using Soxhlet apparatus. It was concentrated to dryness under a controlled temperature of $40-50^{\circ} \mathrm{C}$ and preserved in the refrigerator till further use.

\subsection{Experimental Design}

Male albino rats (40) were obtained from the Centre for Laboratory Animal Research (CLAR). The experiments were designed and performed according to the ethical norms approved by CPCSEA, India, protocol number of approbation allocated for the Institutional Animal Ethical Committee (IAEC) of Saveetha institute medical and technical sciences, Chennai, Tamil Nadu and the approved protocol for the present study was BRULAC/SDCH/SIMATS/IAEC/3-2020/050. The animals were housed (4 rats per cage) in an environmentally controlled temperature $\left(22 \pm 2^{\circ} \mathrm{C}\right)$ with a $12: 12$-hr light/dark cycle and they were fed with a standard laboratory diet and had free access to water. Initial $\mathrm{LD}_{50}$ studies were carried out to determine the maximum dose that did not produce any death in the rats. The experimental animals were divided into 10 groups of 4 animals. Animal of Group I served as normal received distilled water, Group II animals were administered orally $15 \mathrm{mg} / \mathrm{Kg}$ body weight of lead acetate (LA), ones in a week for 32 days, Group III to $\mathrm{V}$ animals received EPPF $150 \mathrm{mg} / \mathrm{kg}, 300 \mathrm{mg} / \mathrm{kg}$ and 600 $\mathrm{mg} / \mathrm{kg}$ respectively, Group VI animals standard silymarin 50 $\mathrm{mg} / \mathrm{kg}$, Groups VII to X were treated with LA (15 mg/kg) with EPPF $150,300,600$ and silymarin $50 \mathrm{mg} / \mathrm{kg}$, orally for 32 days respectively. The rats were anesthetized using chloroform vapour before dissection at the end of the treatment period. Blood samples were collected by cardiac puncture into two different tubes, one containing anticoagulant (EDTA) and the other without anticoagulant. The EDTA was added to the blood in the tube for the determination of hematological parameters and without EDTA was used for the preparation of serum samples. For serum separation from blood, the blood was permitted to clot by keeping at room temperature for 1 hour and then refrigerated for another $1 \mathrm{~h}$. The resultant fluid portion was centrifuged at $1000 \mathrm{rpm}$ for $10 \mathrm{~min}$, and then the clear serum (supernatant) was separated and stored at $-30{ }^{\circ} \mathrm{C}$ until required for analysis (Tuck et al., 2009). 

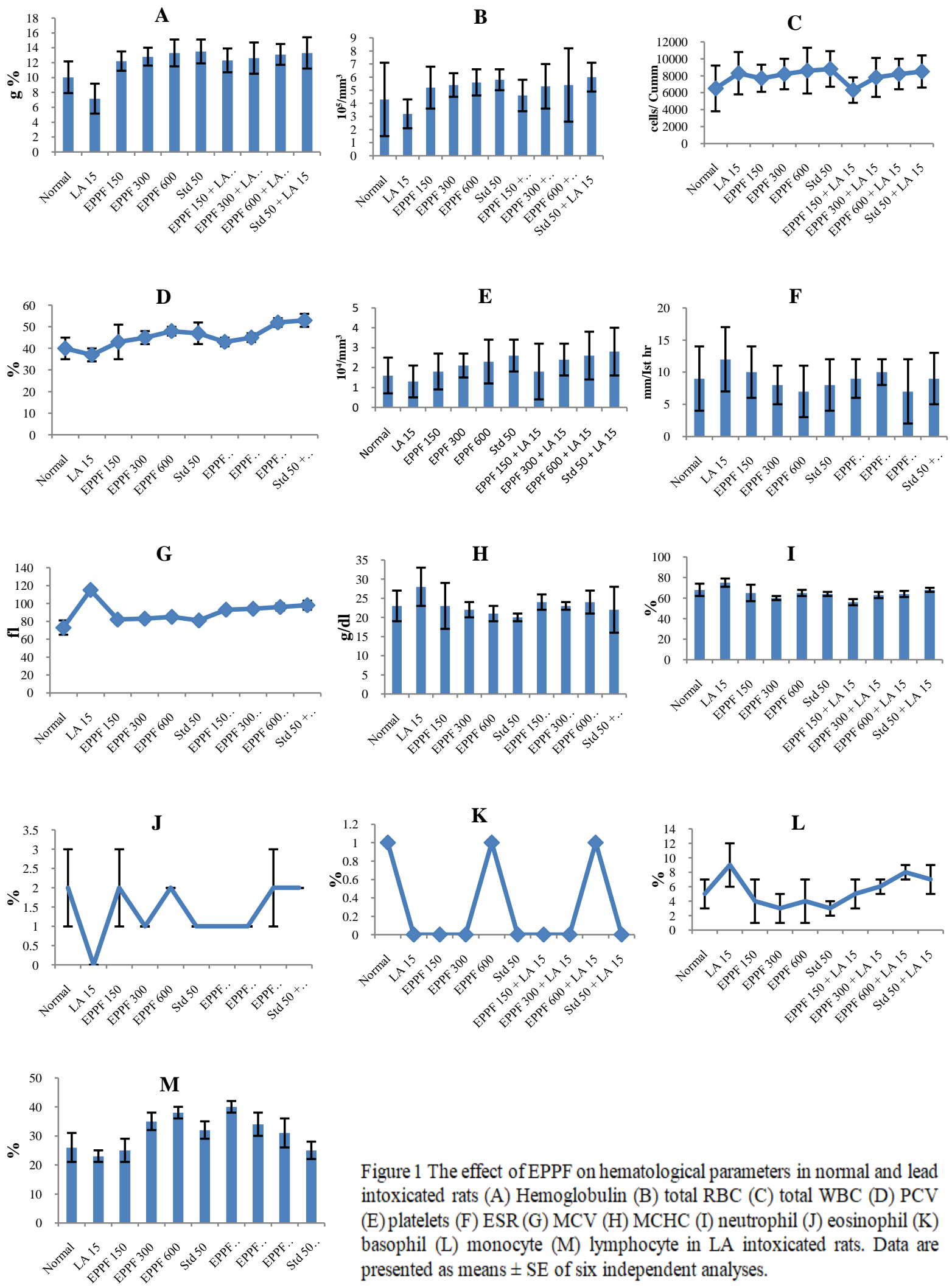

Figure 1 The effect of EPPF on hematological parameters in normal and lead intoxicated rats (A) Hemoglobulin (B) total RBC (C) total WBC (D) PCV (E) platelets (F) ESR (G) MCV (H) MCHC (I) neutrophil (J) eosinophil (K) basophil (L) monocyte (M) lymphocyte in LA intoxicated rats. Data are presented as means \pm SE of six independent analyses. 

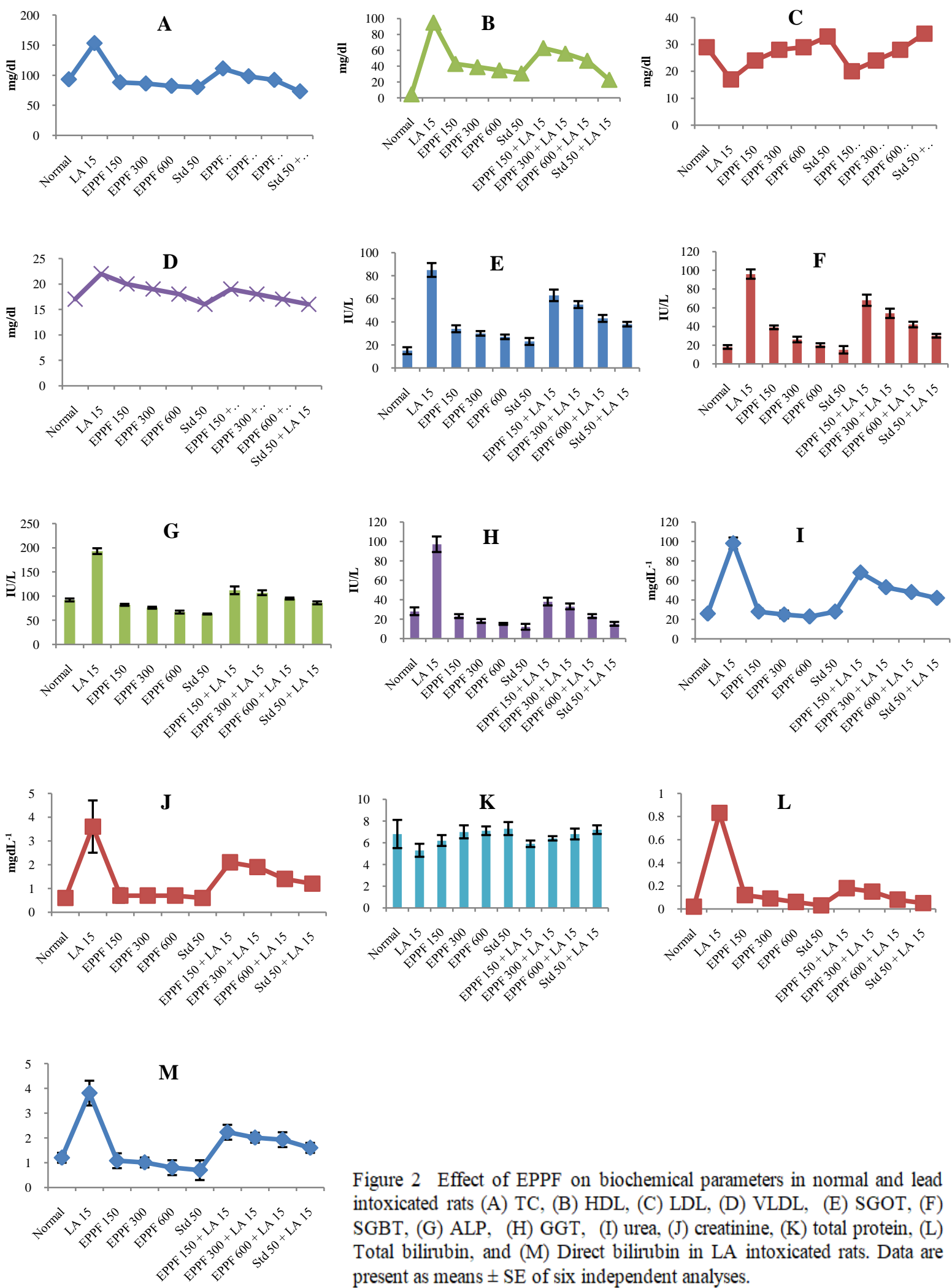

Figure 2 Effect of EPPF on biochemical parameters in normal and lead intoxicated rats (A) TC, (B) HDL, (C) LDL, (D) VLDL, (E) SGOT, (F) SGBT, (G) ALP, (H) GGT, (I) urea, (J) creatinine, (K) total protein, (L) Total bilirubin, and (M) Direct bilirubin in LA intoxicated rats. Data are present as means $\pm \mathrm{SE}$ of six independent analyses. 


\subsection{Hematological parameters}

The hematological parameters including hemoglobin $(\mathrm{Hb})$, Total RBC, Total WBC, packed cell volume (PCV), platelets, mean corpuscular volume (MCV), mean corpuscular hemoglobin concentration (MCHC), neutrophil, eosinophil, basophil, monocytes, lymphocytes, and erythrocyte sedimentation rate (ESR) were analyzed by the method of Barbara \& Brown (1980).

\subsection{Biochemical analysis}

Serum samples collected from different groups were analyzed for urea, creatinine, total cholesterol, high-density lipoproteins (HDL), low-density lipoproteins (LDL), very low-density lipoprotein (VLDL), bilirubin (Bil-total \& Bil-direct), SGOT, SGBT, Alkaline phosphatase (ALP), GGT, and total protein as per the colorimetric methods (Reitman \& Frankel, 1957).

\subsection{Statistical analysis}

In the present study, the data were expressed as the mean and standard error of the mean (SEM). Data were analyzed by one way analysis of variance (ANOVA) using the SPSS software.

\section{Results}

The lead acetate administered group (Group II) has exhibited a sudden reduction in the hemoglobulin, total $\mathrm{RBC}, \mathrm{PCV}$, platelets and lymphocytes levels by $7.16 \pm 2.01 \mathrm{~g} \%, 3.2 \pm 1.110^{5} / \mathrm{mm}^{3}$, $37.0 \pm 3.0 \%, 1.3 \pm 0.810^{4} / \mathrm{mm}^{3}$ and $23.0 \pm 2.0 \%$ when compared to normal group which revealed $10.03 \pm 2.13 \mathrm{~g} \%, 4.3 \pm 2.810^{5} / \mathrm{mm}^{3}$, $40.0 \pm 5.0 \%, 1.6 \pm 0.9310^{4} / \mathrm{cu} . \mathrm{mm}$ and $26 \pm 5 \%$, respectively. After the treatment with EPPF along with LA, a significant increase in the total RBC, hematocrit, platelets, and lymphocytes were reported (Fig 1A, 1B, 1D 1E, 1I). The highest amount of Hb, total $\mathrm{RBC}, \mathrm{PCV}$, platelets, and lymphocytes were observed in the LA intoxicated rats treated by $600 \mathrm{mg} / \mathrm{kg}$ of EPPF while the lowest amount was observed in the lowest dose of EPPF $(150 \mathrm{mg} / \mathrm{kg})$. Whereas, the LA alone administered group has shown a elevation in the total WBC $(8300 \pm 2500$ cells/ Cumm), ESR (12.0 \pm 5.0 $\mathrm{mm} / \mathrm{Ist} \mathrm{hr}), \quad \mathrm{MCV}(115.0 \pm 3.0 \%), \quad \mathrm{MCHC} \quad(28.0 \pm 5.0 \mathrm{~g} / \mathrm{dL})$, neutrophil $(75.0 \pm 4.0 \%)$ and monocytes $(9.0 \pm 3.0 \%)$ as compared to the normal group $(6500 \pm 2700$ cells/ Cumm, $9.0 \pm 5.0 \mathrm{~mm} / \mathrm{Ist} \mathrm{hr}$, $73.0 \pm 8.0 \%, 23.0 \pm 40 \mathrm{~g} / \mathrm{dL}, 68.0 \pm 6.0 \%$ and $5.0 \pm 3.0 \%$, respectively). Further, the EPPF alone or the combination of EPPF with LA treated groups reduced the total WBC, ESR, MCV, MCHC, neutrophil, and monocytes counts as compared to LA treated rats and these values are near to control rats $($ Fig $1 \mathrm{C}, 1 \mathrm{~F}, 1 \mathrm{G}, 1 \mathrm{H}, 1 \mathrm{~J}$, $1 \mathrm{~K}, 1 \mathrm{~L}, 1 \mathrm{M})$. Among the three concentrations of EPPF against LA, the highest concentration $(600 \mathrm{mg})$ has registered the very closer value of control rats than others and also almost similar to the standard drug-treated group (Figure 1).
The hepatotoxic agent, LA caused significant liver damage as indicated by an increase in the level of liver chemistry biomarkers such as; cholesterol $\left(153 \pm 5.7 \mathrm{mgdL}^{-1}\right)$, LDL $\left(95 \pm 1.3 \mathrm{mgdL}^{-1}\right)$, VLDL $\left(22 \pm 5 \mathrm{mgdL}^{-1}\right)$, SGOT $(85 \pm 6 \mathrm{IU} / \mathrm{L})$, SGBT $(96 \pm 5 \mathrm{IU} / \mathrm{L})$, ALP $(193 \pm 6 \mathrm{IU} / \mathrm{L})$, GGT $(97 \pm 8 \mathrm{IU} / \mathrm{L})$, urea $\left(98 \pm 6 \mathrm{mgdL}^{-1}\right)$, creatinine $\left(3.6 \pm 1.1 \mathrm{mgdL}^{-1}\right)$ and bilirubin $\left(3.8 \pm 0.5 \mathrm{mgdL}^{-1}\right)$ and a decrease in the level of HDL $\left(17 \pm 1.3 \mathrm{mgdL}^{-1}\right)$ and total protein $\left(5.3 \pm 0.6 \mathrm{mgdL}^{-1}\right)$ when compared to control animal group (Figure 2).

Rats pre- and post-treated with ESSF at $150 \mathrm{mg} / \mathrm{kg}, 300 \mathrm{mg} / \mathrm{kg}$, and $600 \mathrm{mg} / \mathrm{kg}$ doses has significantly reduced the levels of cholesterol, LDL, VLDL, SGOT, SGBT, ALP, GGT, urea, creatinine, bilirubin, and significantly increased the levels of HDL and total protein as compared to the LA administered controls. The observations from the EPPF treatment were very closer to the normal group. The data of the results very clearly depicted that the selected fruit extract has promising protective efficacy against lead acetate-induced liver toxicity at the dose of $600 \mathrm{mg} / \mathrm{kg}$ as compared to that of the other two lower doses and the results were compared with standard drug silymarin (Figure 2).

\section{Discussion}

Nowadays, liver disorders are amongst the most serious health issues in the world and their management and treatment options remain limited despite remarkable signs of progress in modern medicine. Therefore, testing and the use of botanical hepatoprotective agents are substantially increasing. Lead acetate, a potent hepatotoxic agent, is the most widely used criterion for evaluating the hepatoprotective activity of plant extracts. This study evaluated the antihepatotoxic capacity of $P$. peruviana fruit against lead acetate-induced hepatotoxicity in albino rats. Results of the present study are in agreement with the findings of previous researchers who reported the hepatoprotective potential of the various fruits extracts such as fruits of Musa paradisiaca (Issa et al., 2018), Passiflora edulis (Nerdy \& Ritarwan, 2019), Cordia obliqua (Tharun et al., 2020), Prunus domestica (Soni \& Tanwar, 2020), Terminalia bellirica (Gupta et al., 2021).

The hematological parameters are important indices of the physiological and pathological status of animals and humans (Adeneye et al., 2006). It can also use to determine the extent of the deleterious effect of foreign compounds on the blood of the albino rats (Odeyemi et al., 2009). In the present study, the decreasing amount of $\mathrm{Hb}$, total RBC, PCV, platelets, lymphocytes, and elevated levels of WBC, ESR, MCV, MCHC, neutrophil, eosinophil, basophil, monocytes were observed in LA treated group. The reduction in $\mathrm{Hb}, \mathrm{RBC}$, and PCV are probably due to the production of reactive oxygen species (ROS) under the influence of heavy metal which destroys the red blood cell membrane and its functions (Tariq, 2007). The elevation of WBC, $\mathrm{MCV}$, and $\mathrm{MCHC}$ might be due to the elevated inflammatory 
reaction as a result of lead toxicity. These results are in agreement with the findings of Bersenyi et al. (2003) and Simsek et al. (2009).

Whereas, pre and post-treatment with EPPF reversed the levels of blood parameters as compared with those of the control group. The higher doses $(600 \mathrm{mg} / \mathrm{kg})$ exhibited more effect compared to lower doses, these effects might be because of possessing phenolic compounds such as flavonoids and tannins which possess strong antioxidant activity and may assist to protect the cells against the oxidative damage caused by free-radicals (Sathyadevi \& Subramani, 2015). Phenolic compounds have been proved as metal chelators, radical scavengers, reducing agents, singlet oxygen quenchers, and hydrogen donors (Wong \& Kitts, 2006). As such, these particular secondary metabolites in the $P$. peruviana fruits might have been chelating the lead in the blood and other tissues as well as mopped-up lead-induced free radicals in the blood which will eventually free hematopoietic tissues of oxidative stress. From the present observations, it is revealed that the tested ethanolic fruit extract of $P$. peruviana was devoid of the toxic effect of lead acetate. Thus results of the present study can be concluded that the EPPF showed protective efficacy of lead acetate-induced haemotoxicity in rats.

Serum levels of liver enzymes such as cholesterol, LDL, HDL, VLDL, SGOT, SGBT, ALP, GGT, bilirubin, urea, creatinine, total protein, and globulin are important markers of liver function. In this study, elevated levels of cholesterol, LDL, and VLDL were found in the rats treated with LA which was significantly higher than that of control rats. It might be attributed that lead-induced activation of 3-hydroxy-3- methylglutaryl coenzyme A reductase and HMG CoA synthase (the two rate-limiting enzymes in cholesterol synthesis) or it may be due to feedback inhibition (Sawada et al., 2005). In contrast, marked depletion of HDL was observed in lead acetate intoxicated rats. A liver disorder resulting from exposure to lead acetate has been suggested to decrease the HDL-C content, cause dyslipidemia and disturb the biological functions of HDL-C (Samarghandian et al., 2015). Oral administration of fruit extract significantly prevented the severity of liver damage and thereby marked depletion of cholesterol, LDL, and VLDL and improvement in the level of HDL. These values were closer to the control group animal. Also, a similar result was observed in the standard drug-treated group. Similar observations were reported by previous studies (Jesuorsemwen et al., 2016; AlAttar, 2020; Abdelhamid et al., 2020).

The present study revealed a significant increase in SGPT, SGOT, ALP, and GGT levels in serum at lead acetate treated group than control rats. Liver enzymes such as SGPT, SGOT, ALP, and GGT are marker enzymes for liver function and integrity (Adaramoye et al., 2008). Liver injury following lead exposure is well characterized by elevated levels of plasma hepatic marker enzymes which indicate cellular leakage and loss of functional integrity of hepatic membrane architecture (Al-Attar, 2011; Attia et al., 2013). Oral administration of $P$. peruviana fruit extracts against lead acetate, SGOT, SGPT, ALP, and GGT in serum were improved as compared to the lead acetate treated group. Similar results were reported by Subash et al. (2011), Adewale et al. (2015), and Yogananth et al. (2015).

The elevation in the levels of urea, creatinine, and bilirubin has been reported in LA treated animals when compared to control rats due to lead acetate toxicity caused hepatocyte degeneration and blockage of bile ducts. The treatment of fruit extract in lead acetate intoxicated rats reversed the levels of urea, creatinine, and bilirubin and these parameters were nearer to the control group. The study report was correlated with the previous other studies which have been already reported similar results (Saraswat et al., 1993; Murugavel \& Pari, 2007; Manna et al., 2008).

In the current study, the rats treated with LA were shown a significant decrease in the levels of serum total proteins and albumin when compared to the control group. There was no significant difference in the level of globulins. This might be due to either poor liver function or liver damage by lead acetate, which is associated with loss of structural integrity of cells (Goswami \& Bhattacharya, 2000). The significant restoration of these trace elements level was found in rats treated with EPPF, but the highest hepatoprotective activity was found in a higher dose of $600 \mathrm{mg} / \mathrm{kg}$ as compared to standard drugs. Similarly, Badr \& Naeem (2019) reported that the total protein, albumin, and globulin reduction by aflatoxin have been improved by $P$. peruviana presence in diets. The study correlated the hepatoprotective activity of $P$. peruviana fruit extract has shown better hepatoprotective activity and it may be due to the presence of alkaloids, phenols, and tannins which exhibited free radical-scavenging and antioxidant activities (Chang et al., 2008; Toro et al., 2013; Hassan et al., 2017).

\section{Conclusion}

From the present studies, it can be concluded that treatment with EPPF has therapeutic value in the management of adverse effects associated with lead exposure, especially on the liver in albino rats, based on the results of this study. The efficacy of the fruit extract of $P$. peruviana would have a wide scope in the future. Hence, this will open a new model for the production of alternative therapeutic medicine for the treatment of the liver injury.

\section{Acknowledgement}

The authors are thankful to the authorities of Sri Akilandeswari Women's College for providing the necessary facility and their encouragement to complete our work.

\section{Conflict of Interests}

The authors declare that they have no conflict of interest. 


\section{References}

Abdelhamid FM, Mahgoub HA, Ateya AI (2020) Ameliorative effect of curcumin against lead acetate-induced hematobiochemical alterations, hepatotoxicity, and testicular oxidative damage in rats. Environmental Science and Pollution Research 27: 10950-10965.

Adaramoye OA, Olajumoke A, Achem J, Fafunso MA (2008) Lipid-lowering effects of methanolic extract of Vernonia amygdalina leaves in rats fed on high cholesterol diet. Vascular Health and Risk Management 4(1): 235-241.

Adebayo SA, Ondua M, Shai LJ, Lebelo SL (2019) Inhibition of nitric oxide production and free radical scavenging activities of four South African medicinal plants. Journal of Inflammation Research 12: 195-203.

Adeneye AA, Ajagbonna OP, Bello SO (2006) Preliminary toxicity and phytochemical studies of the stem bark aqueous extract of Musanga cecropioides in rats. Journal of Ethnopharmacology 105(3): 373-379.

Adewale OB, Oloyede OI, Onasanya A, Olayide II, Anadozie SO, Fadaka AO (2015) Hepatoprotective effect of aqueous extract of Solanum macrocarpon leaves against carbon tetrachloride-induced liver damage in rats. Journal of Applied Pharmaceutical Science 5(2): 81-86.

Al-Attar AM (2011) Hepatoprotective influence of vitamin c on thioacetamide-induced liver cirrhosis in wistar male rats. Journal of Pharmacology and Toxicology 6: 218-233.

Al-Attar AM (2020) Therapeutic influences of almond oil on male rats exposed to a sublethal concentration of lead. Saudi Journal of Biological Sciences 27: 581-587.

Arun M, Asha VV (2007) Preliminary studies on anti-hepatotoxic effect of Physalis peruviana Linn. (Solanaceae) against carbon tetrachloride induced acute liver injury in rats. Journal of Ethnopharmacology 111: 110-114.

Attia FH, Soliman MM, Abdel Rahman GH, Nassan MA, Shimaa AI, Mona F, Carmen S (2013) Hepatoprotective effect of Nacetylcysteine on the toxic hazards of titanium dioxide nanoproticles. American Journal of Pharmacology and Toxicology 8: 141-147.

Azman MA, Hamzah S, Abdul Rahman S, Elias S, Abdullah NA, Hashim A, Shukor SA, Kamaruddin AHC (2015) Trace element analysis of soil type collected from the Manjung and Central Perak. AIP Conference Proceedings 1659(1): 5.
Badr AN, Naeem MA (2019) Protective efficacy using Capegolden berry against pre-carcinogenic aflatoxins induced in rats. Toxicology Reports 6: 607-615.

Barbara AJ, Brown MS (1980) Haematology: Principles and procedures, $3^{\text {rd }}$ Edition, lea and febiger, Philadelphia.

Bersenyi A, Fekete S, Szoes Z (2003) Effect of ingested heavy metals $(\mathrm{Cd}, \mathrm{Pb}$ and $\mathrm{Hg})$ on haematology and serum biochemistry in rabbits. Acta Veterinaria Hungarica 51: 297-304.

Cakir O, Pekmez M, Cepni E, Candar B, Fidan K (2014) Evaluation of biological activities of Physalis peruviana ethanol extracts and expression of Bcl-2 genes in HeLa cells. Food Science and Technology (Campinas) 34(2): 422-430.

Chang JC, Lin CC, Wu SJ, Lin DL, Wang SS, Miaw CL, Ng LT (2008) Antioxidative and hepatoprotective effects of Physalis peruviana extract against acetaminophen-induced liver injury in rats. Pharmaceutical Biology 46(10-11): 724-731.

Chang LC, Sang-Ngern M, Pezzuto JM (2016) Poha Berry (Physalis peruviana) with potential anti-inflammatory and cancer prevention activities. Hawaii Journal of Medicine and Public Health 75(11): 353.

Chaurasia MK, Nizam F, Ravichandran G, Arasu MV, Al-Dhabi NA, Arshad A, Elumalai P, Arockiaraj J (2016) Molecular importance of prawn large heat shock proteins 60, 70 and 90. Fish and Shellfish Immunology 48: 228-238.

Eken A, Unlu-Endirlik B, Baldemir A, Ilgun S, Soykut B, Erdem O, Akay C (2016) Antioxidant capacity and metal content of Physalis peruviana L. fruit sold in markets. Journal of Clinical and Analytical Medicine 7(3): 291-294.

El-Neweshy MS, El-Sayed YS (2011) Influence of vitamin C supplementation on lead-induced histopathological alterations in male rats. Experimental and Toxicologic Pathology 63: 221-227.

Gagan F, Deepesh G, Archana T (2012) Toxicity of lead: a review with recent updates. Interdisciplinary Toxicology 5(2): 47-58.

Gautam P, Flora SJS (2010) Oral supplementation of Gossypin during lead exposure protects alteration in heme synthesis pathway and brain oxidative stress in rats. Nutrition 26: 563-570.

Goswami K, Bhattacharya B (2000) Lead as an environmental pollutant - Its effect on hepatic functions. Pollution Research 23(1): 13-17.

Gupta A, Ramesh K, Risha G, Amit Kumar S, Harvesh Kumar R, Abhay Kumar P (2021) Antioxidant, anti-inflammatory and hepatoprotective activities of Terminalia bellirica and its bioactive 
component Ellagic acid against diclofenac induced oxidative stress and hepatotoxicity. Toxicology Reports 8: 44-52.

Hassan HA, Ghareb NE, Azhari GF (2017) Antioxidant activity and free radical-scavenging of Cape gooseberry (Physalis peruviana L.) in hepatocellular carcinoma rats model. Hepatoma Research 3: 27-33.

Hassanien MFR (2011) Physalis peruviana: A rich source of bioactive phytochemicals for functional foods and pharmaceuticals. Food Reviews International 27: 259- 273.

Higaki R, Chang LC, Inouye DK, Sang-ngern M (2016) Antibacterial activity of extracts from Physalis peruviana (Poha Berry). Journal of Health Disparities Research and Practice 9(1): 57-58.

Hu D, Huang J, Wang Y, Zhang D, Qu Y (2014) Fruits and vegetables consumption and risk of stroke: A meta-analysis of prospective cohort studies. Stroke 45: 1613-1619.

Issa MT, Agbon AN, Balogun SU, Mahdi O, Bobbo KA, Ayegbusi FO (2018) Hepatoprotective effect of methanol fruit pulp extract of Musa paradisiaca on carbon tetrachloride-induced liver toxicity in Wistar rats. Journal of Experimental and Clinical Anatomy 17: 1-7.

Jesuorsemwen EB, Ebikere II, Ozede IN, Anre AFE (2016) Hematobiochemical changes of lead Poisoning and amelioration with Coconut (Cocos nucifera L.) water in Wistar albino rats. Journal of Applied Sciences and Environmental Management 20(1): 89-94.

Joshi K, Joshi I (2015) Nutritional composition and biological activities of Rasbhari: An overview. International Journal of Recent Scientific Research 6(11): 7508-7512.

Kasali FM, Kadima NJ, Mpiana PT, Ngbolua JPK, Tshibangu DS (2013) Assessment of antidiabetic activity and acute toxicity of leaf extracts from Physalis peruviana (L.) in guinea-pig. Asian Pacific Journal of Tropical Biomedicine 3(11): 885-890.

Kumaresan V, Ravichandran G, Nizam F, Dhayanithi NB, Arasu MV, Al-Dhabi NA, Harikrishnan R, Arockiaraj J (2016) Multifunctional murrel caspase 1, 2, 3, 8 and 9: Conservation, uniqueness and their pathogen-induced expression pattern. Fish and Shellfish Immunology 49: 493-504.

Lashin II, Elhaw MH (2016) Evaluation of secondary metabolites in callus and tissues of Physalis peruvianna. International Journal of Modern Botany 6(1): 10-17.

Manna P, Sinha M, Sil PC (2008) Arsenic-induced oxidative myocardial injury: protective role of arjunolic acid. Archives of Toxicology 82(3): 137-149.
Soni M, Tanwar YS (2020) Hepatoprotective activity of Prunus domestica fruit extract against paracetamol-induced liver damage in albino rats. Journal of Critical Reviews 7(15): 4729-4734.

Mobarak YMS, Sharaf MM (2011) Lead acetate-induced histopathological changes in the gills and digestive system of silver sailfin molly (Poecilia latipinna). International Journal of Zoological Research 7: 1-18.

Murugavel P, Pari L (2007) Effects of diallyl tetrasulfide on cadmium-induced oxidative damage in the liver of rats. Human and Experimental Toxicology 26(6): 527-534.

Nerdy N, Ritarwan K (2019) Hepatoprotective activity and nephroprotective activity of peel extract from three varieties of the passion fruit (Passiflora sp.) in the albino rat. Macedonian Journal of Medical Sciences 7(4): 536-542.

Nwokocha CR, Owu DU, Nwokocha MI, Ufearo CS, Iwuala MO (2012) Comparative study on the hepatoprotection to heavy metals of Zingiber officinale. Pharmacological Research 4: 208-213.

Odeyemi OO, Yakubu MT, Masika PJ, Afolayan AJ (2009) Toxicological evaluation of the essential oil from Mentha Longifolia L Suosp. capensis leaves in rats. Journal of Medicinal Food 12(3): 669-674.

Osorio-Guarin JA, Enciso-Rodríguez FE, González C, FernándezPozo N, Mueller LA, Barrero LS (2016) Association analysis for disease resistance to Fusarium oxysporum in cape gooseberry (Physalis peruviana L). BMC Genomics 17: 248.

Park EJ, Sang-Ngern M, Chang LC, Pezzuto JM (2016) Induction of cell cycle arrest and apoptosis with down regulation of Hsp90 client proteins and histone modification by $4 \beta$-hydroxywithanolide E isolated from Physalis peruviana. Molecular Nutrition and Food Research 60: 1482-1500.

Reitman S, Frankel S (1957) Colourimetric method for the determination of serum oxaloacetic and glutamic pyruvic trasaminase. American Journal of Clinical Pathology 28: 56-63.

Samarghandian S, Nezhad MA, Mahmoud M, Shabestari MM, Azad FJ, Farkhondeh T, Bafandeh F (2015) Effect of chronic exposure to cadmium on serum lipid, lipoprotein and oxidative stress indices in male rats. Interdisciplinary Toxicology 8(3): 151-154.

Saraswat B, Visen PK, Patnaik GK, Dhawan BN (1993) Anticholestic effect of picroliv, active hepatoprotective principle of Picrorhiza kurrooa against carbon tetrachloride induced cholestatis. Indian Journal of Experimental Biology 31: 316-318.

Sathyadevi MS, Subramani SS (2015) Extraction, isolation and characterization of bioactive flavonoids from the fruits of Physalis 
peruviana Linn extract. Asian Journal of Pharmaceutical and Clinical Research 8(1): 152-157.

Sawada A, Nishizaki Y, Sato H, Yada Y, Nakayama R, Yamamoto S, Nishioka N, Kondoh H, Sasaki H (2005) Tead proteins activate the Foxa2 enhancer in the node in cooperation with a second factor. Development 132: 4719-4729.

Sharma S, Sharma V, Paliwal R, Pracheta (2011) Lead toxicity, oxidative damage and health implications. A review. International Journal of Biotechnology and Molecular Biology Research 2: 215 221.

Simsek N, Karadeniz A, Kalkan Y, Keles ON, Unal B (2009) Spirulina platensis feeding inhibited the anemia- and leucopeniainduced lead and cadmium in rats. Journal of Hazardous Materials 164:1304-9.

Subash KR, Ramesh KS, Charian BV, Britto F, Jagan Rao N, Vijaykumar S (2011) Study of hepatoprotective activity of Solanum nigrum and Cichorium intybus. International Journal of Pharmacology. 7: 504-509.

Tariq HA (2007) Comparative study between chronic effects of lead and copper on haematology parameters. SGH Medical Journal 2: $22-29$.

Tharun G, Sivakrishnan S, Sharma JVC (2020) Toxicity assessment, evaluation of antioxidant and hepatoprotective activity on Cordia obliqua fruit extracts. Pharmacognosy Journal 12(5): 1005-1011.
Toro RM, Aragón DM, Ospina LF (2013) Hepatoprotective effect of calyces extract of Physalis peruviana in hepatotoxicity induced by $\mathrm{CCl} 4$ in Wistar rats. Vitae 20: 125-132.

Tuck MK, Chan DW, Chia D, Godwin AK, Grizzle WE, Krueger KE, Rom W, Sanda M, Sorbara L, Stass S, Wang W, Brenner DE (2009) Standard operating procedures for serum and plasma collection: early detection research network consensus statement standard operating procedure integration working group. Journal of Proteome Research 8(1): 113-117.

Vineeth Daniel P, Kamthan M, Gera R, Dogra S, Gautam K, Ghosh D, Mondal P (2019) Chronic exposure to $\mathrm{Pb}^{2+}$ perturbs $\mathrm{Ch}$ REBP transactivation and coerces hepatic dyslipidemia. FEBS Letters 593: 3084- 3097.

Wang X, Ouyang Y, Liu. J, Zhu M, Zhao G, Bao W, Hu FB (2014) Fruit and vegetable consumption and mortality from all causes, cardiovascular disease, and cancer: Systematic review and doseresponse metaanalysis of prospective cohort studies. BMJ 349:4490.

Wong PY, Kitts DD (2006) Studies on the dual antioxidant and antibacterial properties of parsley (Petroselinum crispum) and cilantro (Coriandrum sativum) extracts. Food Chemistry 97(3): 505-15.

Yogananth N, Syed Ali M, Anuradha V, Anandha Jothi and Chanthuru A (2015) Utilization of diets amended Pergularia daemia forsk. plant extracts for the control of aflatoxicosis. Journal of Global Biosciences 4(1): 1250-1257.

Journal of Experimental Biology and Agricultural Sciences http://www.jebas.org 